\title{
Guanine synthesis from interstellar organic molecules as an example of prebiotical chemistry
}

\author{
Adriana Patricia Lozano Medellin \\ Universidad Nacional de Colombia, Faculty of Science, Department of Chemistry, Colombia \\ email: aplozanom@unal.edu.co
}

\begin{abstract}
The idea that some nitrogen bases, such as adenine and guanine, are easily formed and can be found in interstellar space is should not be rejected. In fact, they have been found in the soluble fraction of some ancient meteors. It is possible that the "seed" of life had its origin in space, and thanks to Earth conditions, a synergistic interaction ocurred and allowed life to spring forth on our planet.
\end{abstract}

Keywords. Guanine, synthesis, prebiotical, chemistry, DNA

\section{Introduction}

Guanine is one of the five main nucleobases found in the nucleic acids DNA and RNA, the others being adenine, cytosine, thymine, and uracil. With the formula $\mathrm{C}_{5} \mathrm{H}_{5} \mathrm{~N}_{5} \mathrm{O}$, guanine is a derivative of purine, consisting of a fused pyrimidine-imidazole ring system with conjugated double bonds.

Two experiments conducted by Levy et al. showed that heating $10 \mathrm{M} \mathrm{NH}_{4} \mathrm{CN}$ at $80{ }^{\circ} \mathrm{C}$ for 24 hours gave a yield of $0.0007 \%$, while using $0.1 \mathrm{M} \mathrm{NH}_{4} \mathrm{CN}$ frozen at $-20{ }^{\circ} \mathrm{C}$ for 25 hours gave a $0.0035 \%$ yield. These results indicate guanine could arise in frozen regions of the primitive Earth.

\section{Theoretical proposal}

Is it possible to make guanine from organic molecules from interstellar space?

The live organisms require a molecular response RNA or DNA, it is vital to understand whether predecessors exist in interstellar space.

This synthesis is proposed as a reaction of hydrogen cyanide molecules with formaldehyde, going through mediators; malonitrile, acid malonic, nitro malonic acid, 2-amino malomic acid, and 3-oxoserinamide. The last, due to cyclization, forms 2-oxo 4,5 dihydro$1 \mathrm{H}$ - imidazole- 4 carboxylic acid. This, because of a hydroxyl functional exchange for chloride and reaction with guanine, forms $1,2,3,9$ tethrahydro $6 \mathrm{H}$ purinone which produces guanine through reduction. As a result, the importance of prebiotic chemistry to generate life is proven.

\section{Acknowledgements}

We thank the IAU 251 Committee for travel support and Airline AVIANCA, and Mary Ruth Garcia Conde, a teacher at the National University of Colombia, and thanks to Ernesto Silva of the Chemistry Department. 


\section{References}

Bada, J. L. 2004, Earth Planet. Sci. Lett., 226, 1

Bennet, J., Shostak, S., \& Jakosky, B. 2003, Life in the Universe, (Addison-Wesley, New York), p. 27

Echols, H. \&, Goodman, M. F. 1991, Ann. Rev. Biochem., 60, 477

Lahav, N. 1999, Biogenesis, Theories of Life's Origin, (Oxford University Press, New York), p. 11

Miller, S. L. 1998, in: Brack, A. (ed.), The endogenous synthesis of organic compounds, The Molecular Origins of Life, (Cambridge University Press, Cambridge), p. 59

Miller, S. L. 1987, Symp. Quant. Biol., 52, 17

Sirover, M. A., \& Loeb, L. A. 1976, Science, 194, 1434

Willians, R. J. 2002, J. Inorg. Biochem., 88, 241

Zubay, G., \& Mui, T. 2001, Orig. Life Evol. Biosph., 31, 87

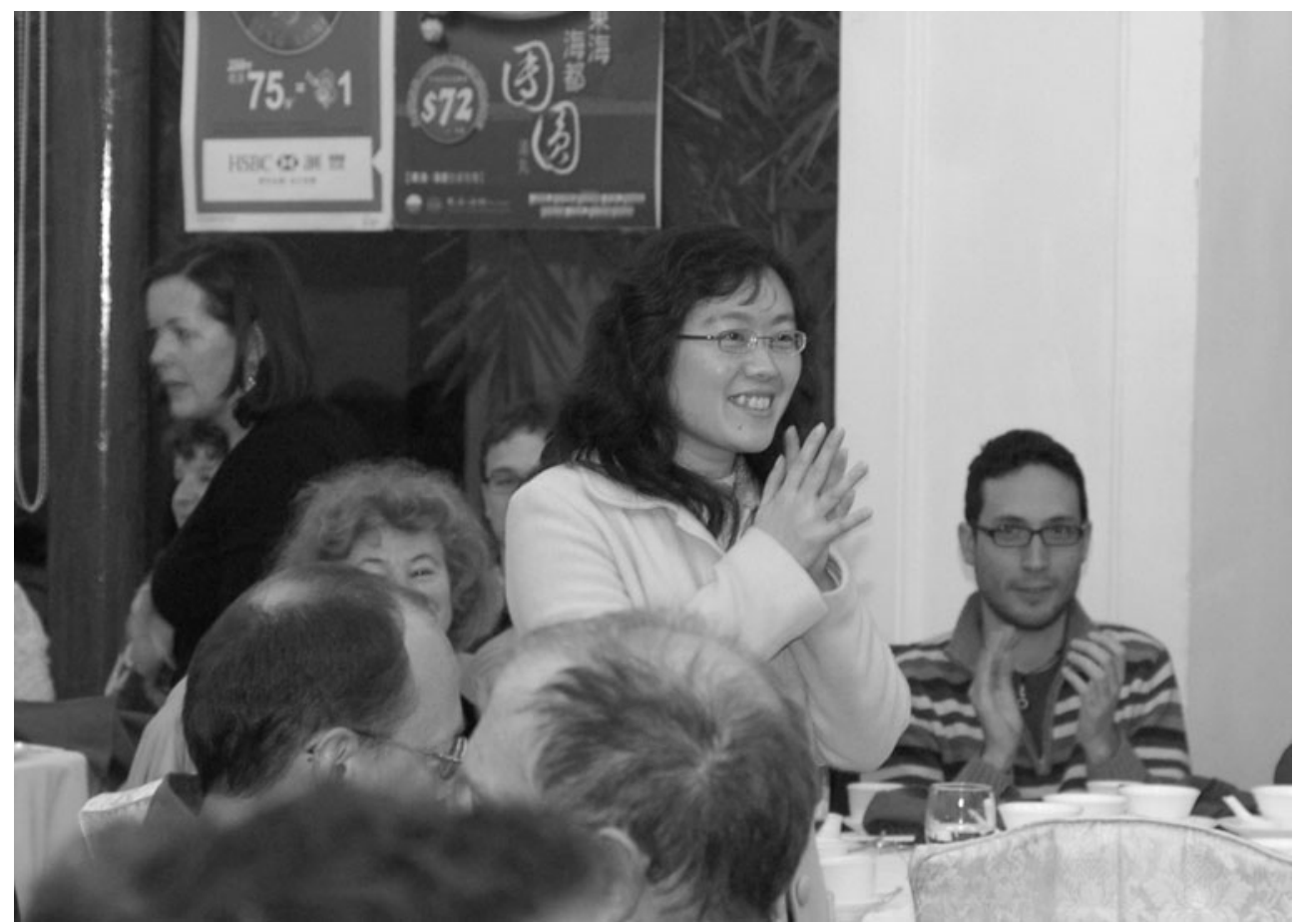

Anisia Tang acknowledging the expression of thanks by the conference participants during the banquet. 